\title{
Participation of women entrepreneurs in northern Nigeria
}

\author{
Jelena Zivkovic
}

\begin{abstract}
This review of literature examines pertinent information concerning the participation of women entrepreneurs, specifically in northern Nigeria. While much has been published about social factors and how those impact the lives of these women, the implications of how such factors affect their earning power had to be inferred. Longstanding cultural attitudes of a male-dominated society coupled with massive poverty have obviously exacerbated the problem, but further investigation of these issues may reveal Nigerian women's longterm potential as entrepreneurs.
\end{abstract}

\section{Introduction}

Nigeria is often referred to as "The Giant of Africa," because it is the continent's most populated nation, with 150 million people who have their origins in no fewer than 250 different ethnic groups. It is a land of dichotomy: Nigerians have been reported to be the happiest people on earth, yet since its independence from Britain in 1960, the nation has gone through a major civil war and a series of brutal military dictatorships. It is the second largest oil producer in Africa, yet $70 \%$ of its population lives below the poverty line. For the past 11 years, the nation has tried to re-establish itself as a democracy, yet ethnic violence between Muslims and Christians is one of the major challenges to the government, along with repetitive violence in the Niger Delta, where oil is produced.

The wealthy people of Nigeria are very wealthy, and much of that wealth stems from involvement in a corrupt government. Outside of the model city of Abuja, which became the nation's capital in 1991, Nigeria is plagued with bad roads, inadequate health care, a failing educational system, and poor infrastructure.

Since the 1970s, the nation has become dependent on oil, but that money does not circulate very much within the massive population. Most Nigerians do not complain about the nation's shortcomings-they are too busy trying to make a living.

There are very few social services in Nigeria. There are no welfare departments, no national retirement penchants, and the present minimum wage is 8000 Naira a month (about \$54 AUSD). The brightest opportunities for most male Nigerians are plum political appointments that pay salaries comparable to those of civil servants in the developed world, but women are rarely eligible. The only opportunities available for most women are home-based micro-businesses, such as cooking, selling goods on the street, or beauty parlor activities performed in the homes of women who can afford those services. Many of these women may feel the necessity to enlarge these services into shop-centered businesses, but rarely have the opportunity to do so. The movement of women into entrepreneurship could be quite advantageous to the economy of Nigeria, and could help break the nation's dependence on the poorly divided oil income.

This paper examines the obstacles that stand between northern Nigerian and entrepreneurship. It also attempts to identify motivating factors and possible role models, and how women can develop the skills to survive in a patriarchal society. Specifically, this paper addresses the following questions:

How can the possibilities of entrepreneurial participation be accessible to northern Nigerian women? Two follow-up questions arise from the first: a) How do socio-cultural factors influence Nigerian women's decisions to engage in entrepreneurial activities? b) How does the state of the national and regional economy impact women's potential to engage in entrepreneurship activities?

The literature review examines academic articles, government documents, and reliable statistical sources. However, while a great deal of material specific to entrepreneurial women in general and some concerning women in business in Nigeria has been published, very little is available concerning women in business in northern Nigeria. This paper focuses on women residents of the northern region because that portion of the population is little understood in terms of the accessibility and sustainability of their entrepreneur contributions. Very little research has been done on this population segment, and little is really known about their potential.

A cursory search of the Internet reveals many different organizations that support and are often created by women in business. However, in Kano - the second largest city in Nigeria with a population of more than 12 million people - there are only two: one for women in the sciences (National Council of Women Scientists) and another aimed at "women in agriculture." The latter group, however, is financed outside of Kano, and in part, outside of Nigeria, and relies on importing trainers. 
Northern Nigeria is populated mostly by Muslims, and in a very real sense, Kano is the Mecca of Islamic Nigeria. Sharia law (Islamic law based on the teachings of the Qur'an) is enforced there, and it is often described as a conservative community with a mixture of cultures, traditions, and religions. Between 1923 and 1954, women were not allowed to inherit farms or houses. Although the Qur'an clearly states that women have the right to inherit property (Surah, 4:7; Hadith), the local Imam (Muslim leader) claimed that "women inheritors became prostitutes" (Pierce, 2003, p. 463).

That decision was rescinded in 1953, but the attitude lingers. In a 1993 independent evaluation of agricultural projects in the Kano area, the World Bank (2009) reported that the projects involved:

...did not provide assistance targeted to women and there was no direct contact. Women have benefited from increased dry season farming on Fulani lands in a number of direct and indirect ways. Gender roles in agricultural activities vary but, in general, women's direct role in the field is limited, whereas they are heavily involved in food processing and preparation for market. Particularly for women who own land there are increased opportunities for renting it to others. At the same time, while rural women's workload may have increased, the benefits justify the extra effort. For the family, as well as for their own incomes, women felt that the changes they associated with the ADP had been positive, even if they had not been directed at them (World Bank Group, 2011).

Islamic culture in Nigeria often discourages women from going outside of their houses to become involved in the business activities and in the professional arena. They are expected to be submissive to their husbands (Surah, 4:34; Hadith).

It is commonly believed in the Muslim community that a woman's primary responsibility is to fulfil her roles as a wife and mother. This is one of socio-cultural factors underpinning the difficulties women confront when they consider entering the professional job market or the field of entrepreneurship.

Married women have to sacrifice a great deal to succeed in business and are not expected to focus on their careers, especially after childbirth. In many cases, women face conflicts with their husbands over such issues (Marković, 2007). The women of northern Nigeria are subject to cultural pressures that impact the larger society: Religious "doctrines" handed down by community spiritual leaders are not open to debate. There is also a palatable notion that internal trading and services contribute little to the economic growth of the Nigeria. The "real" money to be made in Nigeria comes from oil, and politics is about the only route to that money.

In the spring of 2010, it was widely reported that Nigeria had suffered a loss of USD \$20 billion in capital flight, in which the mega-wealthy moved their monies generated within Nigeria to other countries. According to a report by Global Financial Integrity, a Washington, DC-based organization, Nigeria led the continent in capital flight between 1970 and 2008, with a total of $\$ 89.5$ billion (African Confidential, 2010). In a cash-and-carry society, those numbers could be easily underestimated. The impact of those missing funds is hard to overlook. According to the CIA World Fact book, 2011, the average per capita income for Nigeria in 2009 was USD $\$ 2,300$, but that average needs to be considered in light of the fact that the same source estimated that the $10 \%$ of the wealthiest Nigerians account for $32 \%$ of the income - and that is only the visible income. Using data from 2004, the CIA estimated that $70 \%$ of the population lives in poverty.

The money taken from Nigeria does not support the tax base. In fact, $80 \%$ of all government revenue in 2009 came from oil income, and exports of oil represented 95\%nt of foreign exchange earnings (CIA World Fact book, 2011). One of the most misunderstood aspects of the Nigerian economy is the distribution of oil money, or more accurately, the lack of distribution of the nation's oil earnings.

While it does support the government, very little of the money goes beyond a rather small cadre of political leaders (this is one reason why Nigerian elections tend to be so volatile). Internationally, it is known that entrepreneurship and small businesses are the most effective means of creating employment and generating and sustaining tax revenues. With a population of 150 million people, there are definite opportunities in Nigeria for entrepreneurial activities, but these are largely closed to women, especially in the northern region.

Women have traditionally been a part of the Nigerian entrepreneurial scene, but only through homebased micro-enterprises. If effective measures are taken, the contribution of women entrepreneurs to the economic development of the country can be increased.

\section{Challenges Faced by Women Entrepreneurs in Northern Nigeria}

All entrepreneurs face similar problems: raising start-up capital, developing a saleable product or service, and marketing the product or service to gain enough acceptance in the community to eventually let the entrepreneur prosper. It is generally believed that women face more obstacles in these pursuits than men. In much of the world-particularly in developing countries - there are marked differences in educational opportunities for the two genders.

The more male-dominated any culture is, the less appreciation there is of critical thinking (particularly by women), and for the most part, women rarely have the financial connections that men enjoy. 
Nevertheless, these cannot be taken as blanket statements, even in developing countries. For instance, Uganda, again according to the CIA World fact book, has a population of 33 million (about one fifth that of Nigeria). It has lower average per capita annual income (USD $\$ 1,200$ ), yet only $35 \%$ of the population lives below the poverty line. Eighty-three percent of the population purports to be Christians. Uganda is a good example of a progressive culture in which positive attitudes and behaviors are encouraging and supporting entrepreneurial endeavors by either men or women (Uganda Gem Report, 2004).

According to the 2004 GEM report, the perception of cultural norms in that country specifically encourages entrepreneurship. GEM identified five aspects of Ugandan "norms" in that culture that support this:

1. a high level of support for individual success reached by individual efforts;

2. an emphasis on "self-sufficiency, autonomy and personal initiative";

3. encouragement of entrepreneurial risk taking;

4. encouragement of creativity and innovation; and

5. an emphasis on individual responsibility, rather than collective responsibility, that holds that the individual is responsible for managing his or her life. entrepreneurs:

The same report identifies specific aspects of Ugandan life that provide positive support for female

1. sufficient social services to allow women to enter or continue in the workplace even after they start a family (emphasis added);

2. social acceptance of women starting businesses;

3. encouragement for women to start businesses or to be self-employed;

4. equal exposure to opportunities as men; and

5. acceptance of the idea that women have the same skill and knowledge level as men to start a business.

The result is that women entrepreneurs in Uganda are much more positive about their own entrepreneurial roles than are women in some other developing countries (Uganda GEM report 2004).

Positive economic indicators do not necessarily mean more entrepreneurial endeavors. The economic growth of the United Arab Emirates (UAE) is phenomenal by any standard. Again, looking at the CIA World Fact book, the UAE had a per capita income of USD $\$ 38,900$. Five million people lived there in the 2005 , and the nation has the fourth fastest growing population rate in the world.

It is rated number one in the world for migration, and ex-pats constitute $85 \%$ of the labor force. It has a very high literacy rate and, in fact, more women in the country are literate (81\%) than men (76\%). Ninety-six percent of the population adhere to Islam.

In a 2006 GEM report by Kenneth Priess and Declan McCrohon, entrepreneurial activities in the UAE were slight. The report noted that very few men and even fewer women became involved in such activities, but men were much more likely to become involved in a start-up or small business. Although more women responded to the same opportunity, the actual number was miniscule compared with the men, and only slightly higher than the number of start-ups motivated by necessity.

The GEM reports were edifying, particularly in demonstrating cultural differences and identifying different motivations that lead women into entrepreneurship. Beverly Kitching and Atsese Woldie (2004) isolated many common problems among female entrepreneurs worldwide. Much of their information was dated, relying on sources from the 1980s and 1990s.

China was undergoing incredible growth at that time, and when Kitching and Woldie published their paper in 2004, Nigeria had been under civilian rule for only five years. In their primary research in Nigeria, their chief methods were questionnaires and surveys distributed in Lagos and Abuja. Lagos is a coastal city, the former capital of Nigeria, and home to more than 12 million people. Abuja was basically created in 1991 to serve as the nation's capital, and has a population of less than a million.

The remaining research for this paper will look specifically at women in business in the northern sector of Nigeria, and even more specifically, in Kano, the second largest city in Nigeria and the most important city, both economically and culturally.

Some of the general problems northern Nigerian women entrepreneurs face are investigated below.

\section{Lack of financing}

This is one of the main problems women entrepreneurs face. They cannot offer tangible assets to establish their businesses. Many do not hold any property. For this reason, banks and other financial institutions are hesitant to lend money to women who aspire to become entrepreneurs; moreover, there is an apprehensive attitude on the part of these banks and financial institutions towards women entrepreneurs. In Nigeria, wages are low for men and even lower for women. If any kind of credit is available to a family, it will be held by the man. Also, men are much more likely to be in situations to increase their incomes by nefarious means. In Adamawa state, for instance, police are paid 20,000 Naira per month, or approximately USD \$133. Yet police in the state 
are famous for stopping motorists and "fining" them N2,000 (Nigerian Naira), equivalent to USD $\$ 13$, for various road infringements such as not having a fire extinguisher in the car. Tickets are rarely written for the offenses; however, the police openly and forcibly demand discrete payment, which is never recorded. It is common knowledge that although some women are on the state police force, they are rarely the recipients of these impromptu payments.

The American University of Nigeria, which is located in Adamawa State (the northern region), employs about a dozen drivers at N20,000 a month plus health-care benefits for themselves and their families, but employs no women drivers. Women who work full-time as secretaries for private businesses in Adamawa state earn about N6,000 per month, or about USD $\$ 40$.

To say corruption is rampant in Nigeria is almost redundant, but usually, only men find themselves in a position to take advantage of that situation. There is a local political pay-off system in which political supporters of local political officer holders are signed on to the payroll as "administrative assistants" and paid N20,000 monthly, and their one appointed task is to pick up their pay checks.

In 2004, the Nigerian government published a 172-page draft document titled "Nigeria National Economic Empowerment and Development Strategy (NEEDS)." One sentence on page 58 was devoted to "Women's Rights Issues," stating the matter would be looked into. On page 99, a longer paragraph mentioned a UNICEF-funded report titled "Children's and Women's Rights in Nigeria: A Wake Up Call," but the report was not quoted or described. On page 107, a short section on women's and youth's empowerment promised 30\% representation of women in all forms of national life and improved micro-financing to women "with a view to reducing feminized poverty". Whether if a final report was ever made public is unknown.

Very often, women are equated with children, and this is truer in the north than the south. Bankers do not lend money to children. This in itself forces many potential women entrepreneurs to give up their plans to start new ventures.

\section{Lack of education}

In Nigeria, most of the people are poorly educated, contributing to a great deal of social inequality. The existence of social inequality implies high levels of gender discrimination. The wife of Benue State governor Archbishop Yemisi Dooshima Suswam (2010) said at a press conference, “...the low literacy rate in our country especially amongst women folk is due to the high level of poverty bedeviling the society as no society can grow economically if its citizens lack basic education." Education and training in all forms, she continued, "...contributes to a transformation of power relations by giving women access to information, knowledge and skills as women's education has always lagged behind in relation to their male counterparts."

There is a strong presumption in Nigerian culture that a woman's basic and sometimes only role in society is ensuring the continuity of the family line. She is expected to marry young and assume the role of motherhood. In line with that, formal education of young women is not a high priority. Since sound academic training is often a major factor in high level decision-making in both business and government, most northern Nigerian women find themselves outside the decision-making processes that impact their lives.

Suswan (2010) continued:

Women have been conditioned by historical circumstances, religion and tradition to hesitate, even to be reluctant, to take high responsibilities in politics even when they have considerable education. As long as gender discrimination and cultural stereotypes continue to limit women's choices and options, the desire of the nation in achieving economic growth and development will be hampered.

\section{Higher rates of poverty and interest}

Poverty in Nigeria as a whole is very high, limiting all entrepreneurial opportunities. Without efforts to eradicate or reduce poverty, women experience problems in accumulating the monetary means to establish enterprises. Moreover, in a country affected by poverty, it is difficult for many women to think about starting a business enterprise. High rates of interest (20 to 30\%) set by financial institutions can be another problem that force women to give up the option of finding loans to support their businesses.

\section{Inadequate marketing awareness}

It is difficult for women to freely and openly carry out market research and surveys in public settings where mixing with men is frowned upon. Women will instead engage intermediaries, usually male family members or other men within the community. Despite their relationships, these intermediaries may extort large amounts of money from women entrepreneurs.

Moreover, in Nigeria there are restrictions, more cultural than religious, that prohibit women from conversing with unfamiliar men, hence preventing them from collecting data, information, and sources. Islamic law holds that women are unique and independent human beings. A woman has the same responsibilities toward God, family, other human beings-including herself—that a man does. Men and women will be punished 
equally for their transgressions in the hereafter. However, in practice in this culture, limitations are placed upon women in terms of movement, travel, and the places where they can be seen. This means that women entrepreneurs find it difficult to reach the market due to the social and religious system prevailing in the country.

\section{Keen competition}

The poverty of Nigeria raises the stakes in any business encounter. Recently at the American University of Nigeria, one of the "Use-Me" drivers (taxi drivers) who cater to the students called out to a prospective client and got the fare. The driver was an Igbo (one of 122 different tribes in Nigeria) man, and the Fulani (tribe) drivers banded together, went to his house, and beat him. Violence is common in Nigeria, and not uncommon in the business world (Malgwi, 2010). Women do not have this option. There was abundant news coverage of ethnic violence between 2008 and 2010, and it is always interpreted as violence between tribes or religion, but in the end, it is always founded on economic competition, whether that be in terms of government control or control of the land base. Although women and children die by the hundreds in these conflicts, they never have input into planning them.

Major competition from their male counterparts is another problem women entrepreneurs face. They cannot get enough help from advertising or selling agencies. This demotivates potential women entrepreneurs.

\section{Family responsibilities}

Like many women in the world, northern Nigerian women are responsible to and for their families. This is another factor that demotivates woman entrepreneurs. Anecdotal evidence I have gathered indicates that many Nigerian men simply do not know how to do many household chores. They do not know how to cook, and many are surprised when single men from the "west" do their own cooking. Nigerian men often make the important decisions about their children, but do not feel that childcare is part of their duty.

\section{Low mobility}

Low mobility is another problem hindering trade and commerce in Nigeria, where most people make one move in their life: They move from their village to an urban area. If it is possible for them to travel, they will return to the village for holidays and visits, and it remains an important part of their life. On June 6, 2005, John Alkali, then-Secretary of Nigeria's Federal Ministry of Housing and Urban development, addressed this issue in a speech to the Conference of Planning Sustainable Urban Growth and Sustainable Architecture at the United Nations Headquarters. At that time, Alkali put the urban population of Nigeria at $48.2 \%$, and noted that there were 840 urban areas and more than 10 Nigerian cities that had populations of more than a million. Lagos, the former capital and the largest city in Nigeria, he pointed out, had a population larger than 32 African countries, and he predicted that by $2025,60 \%$ of the Nigerian population would live in cities. What Lagos is to the south, Kano is to the north, with a population of more than 12 million.

Still, there is an important cultural difference between these two urban centers that has to do with tribalism in Nigeria. Most Nigerians relate to some tribe, but in the north, the only two tribal affiliations that are politically and culturally acceptable are Hausa and Fulani-and Hausa would be more accurately described as a major African language group (in fact, it is the largest language group in Africa). But the largest single city of Hausa speakers in Africa is Kano, and there, Hausa is synonymous with Islam.

\section{Low social capacity to bear risk}

The social pressure on women in northern Nigeria involves their status as mothers, wives, and homemakers. Entrepreneurial endeavors inevitably involve risk, and many Muslim women would avoid risk if it meant any trade-off involving their obligations to their family or husbands. In this particular culture, a wife is expected to guard her husband's property, which also means that it would be incumbent upon her not to risk his money in any kind of investment. She is also required to "cooperate and coordinate" with her husband, but in reality, this requires her to acquiesce to his decisions (Ali, n.d.).

Although not an exhaustive exploration of the problems and issues faced by women, these challenges to promoting entrepreneurship by women in northern Nigeria are persistent. Few have been adequately explored in the secondary research material, which itself reflects far-reaching prohibitions placed upon these women.

\section{Solutions}

There has been little research on the role of northern Nigeria women in entrepreneurship; however, there is a growing body of information concerning the potential of Islamic women's entrepreneurial participation in other nations. In some cases, solutions have been quantifiably successful. Nevertheless, a certain amount of primary research is necessary to determine whether these same solutions would be applicable to the northern Nigeria setting. 


\section{1) Expanding knowledge of successful Muslim entrepreneurs}

Many Muslim women have attained some level of success without sacrificing their religious beliefs. Their stories abound in the popular and Internet press. Shahnaz Taplin-Dhinoy (2006) told the story of several Muslim women who were pushed into business by divorce or death. These women included a 47-year-old widow who took over her late husband's chicken business, a 55-year-old divorcee who financed her kiosk by selling her jewelery, and a 31-year old single candle-maker who procured a loan to buy the raw materials to work full-time. All these women are deeply religious, yet were impacted by the local and global economy. While local economies dictated their business strategies, they found business methods that allowed them to retain their traditional religious and cultural ethics.

Taplin-Chinoy also pointed to another change in the Islamic world. In the 21st century, more than half of all college graduates in Syria, Palestine, and Jordan are women, many of whom choose to go into business with the support of the men in their families and community.

\section{2) Integrating workable entrepreneurial models with existing social mores}

Despite the image of Islamic life as static, Muslims are changing with the world. A post on eArabgirls.com (2009) offered a Muslim woman's point of view:

In the present world the shifting role of Muslim women in their homes and in the working world provides a new market for financial institutions. In order to tap into this growing segment of the financial industry, banks need to understand the unique banking needs of this vital customer segment and implement a sound training program to best sell and service them. Through training, banks can build a knowledgeable, professional and sensitive staff that is prepared to serve women throughout the Muslim world as this market continues to grow. The recent rise in this market can be attributed to the increasing role of Muslim women in the workplace. Responsible for controlling household and family finances for decades, women have also experienced new empowerment and freedom in how they spend their money.

With new opportunities for education on the rise and more and more women entering the workforce, women have become crucial target customers to the financial industry. Banks can tap into this growing market by providing banking services to their growing number of female customers and by training their sales and customer service personnel to better sell and service this important customer segment.

Today, many Muslim women have significant liquid assets, partly because of Islamic inheritance law. Islamic law dictates that a married woman's wealth is her own; spending on the household is her husband's responsibility. Muslim women are legally entitled to inherit and bequeath property, holding their wealth in their own names even after marriage, without obligation to contribute that wealth to their husband or their family.

The conservatism of traditional Islamic culture in northern Nigeria is well-known, but the Muslim women there often face the same financial events that have compelled women in other Muslim communities to move into business. The events in other parts of the Islamic world could be valuable guidelines to help them establish themselves in entrepreneurial roles, and other Muslim women could become valuable role models.

\section{Providing training and development programs}

The women entrepreneurs should avail themselves of training and development programs to get up-todate knowledge about the latest technologies and business developments.

While the solutions presented are limited, primary research in this geographic area should provide pathways to define new solutions that would be both sustainable and culturally acceptable.

\section{Socio-cultural Influence on Economic Status}

Nigerian women, especially from the northern region, are considered subjugated. It is commonly believed that there is no role for women in the economic development of a country, and they are supposed to stay in the home. The role of Muslim women in the economic development of the society has always been a matter of discussion.

The social situation of the Hausa women in northern Nigeria is that they are supposed to be homebound. The economic aspect of the family will be looked after by men, and they will give the social security required for their female counterparts. Women play minimal roles in decision-making. In the urbanization of Nigeria, the basic model has been that young men go to cities, while women are left behind to tend to the house and farm responsibilities (Meijerink \& Roza, 2007). This is truer in the north than the south.

Many women in northern Nigeria strictly follow the Islamic rule of not interacting with males who are not members of their families. The interaction of men and women in one place, the crowding of them together, and the revealing and exposure of women to men are prohibited by the law of Islam (Sharia, 53, Hadith). If women are working in a factory or business organization, they have to interact with colleagues who most often will be men. This is why many Muslim women do not become part of the economic development of the country 
by becoming an employee or entrepreneur. Despite this, some women entrepreneurs in northern Africa including Nigeria have succeeded in their businesses.

The political system in the country is one of the main reasons for high levels of gender inequality in business or employment. If the political system is responsible, reforming it can reduce gender inequality considerably, thereby bringing more women entrepreneurs to the forefront of Nigerian society.

Even though some positive advances have recently occurred in the education of women in Nigeria, their participation in economic development and policy-making of the country remains largely unchanged. Compared with male entrepreneurs, women cannot easily compete due to many social restraints.

Male domination is always present in almost all aspects of Nigerian economic, social, political, and cultural life, including business and employment. Male employers are generally interested in appointing men, based on the false and misogynist assumption that males constitute a superior type of employee.

Different issues need special attention when one is discussing the entry of northern Nigerian women into business sector. Some are cultural prohibitions of opportunities to achieve economic objectives by starting up new ventures, the lack of support from male counterparts to achieve business success, and the influence of the gender discrimination in management.

Literature on women entrepreneurship in poor countries like Nigeria is scarce. According to a study by the Women Advocates Research and Documentation Centre (2003), the participation of women in social and political decision-making is very low in developing countries. This means that males neglect to see to it that women can enter into leadership positions in different areas of economic, social, political, and cultural life. Research reveals that in Islamic northern Nigeria, male domination is even more stringent (Gender Audit, 2003, p. 17).

As far as urban Nigeria is concerned, participation of women in the informal economic sector is also very slight. It is clear that there is very good potential for women to become successful women entrepreneurs if they are given enough opportunities in all economic sectors of the country. According to Soetan (1995), continuous effort on the part of the government and concerned authorities could change the situation. Although the government is taking some measures to improve small-scale business organizations, priority must be placed on programs for women entrepreneurs (Ogbu, 1995).

The Nigerian constitution does not specifically guarantee any rights to women, and the economic and legal rights they have are often ignored. Traditional bias against women runs deep in the culture, and often results in failure to enforce laws when women are involved. A woman's rights in Nigeria will often depend on her social status, and there are obvious gaps in the treatment of women. Beyond that, like many people in Nigeria, many women simply are unaware of their rights (Isiramen, 2002).

In northern Nigeria, Islamic teachings have a major impact on women's lives. While some women form Qur'an study groups, these groups reflect the traditional male-oriented views of Islam, reinforcing a subservient role for women. Even their movement is restricted. A wife, child, or unmarried female can be stopped from leaving the country by a husband or father, simply by having the authorities take her passport (Isiramen, 2002).

Since the present democratic government came into power in 1999, many if not most communities in northern Nigeria have opted for Sharia, which means that there is a duality of law. Men can opt out of this situation; women cannot. Women who work as domestic help have virtually no rights, and cases of abuse are not uncommon (Nigeria Human Rights Report, 2010). Women certainly do not have equal economic rights in terms of employment and entrepreneurial contributions, and while a married woman may have some rights, single women have fewer. All this underscores the patriarchal nature of Islam as it is practiced, and the control men have over women is something that Nigerian women cannot ignore and often cannot overcome (Nigeria Human Rights Report, 2010).

However, some of these problems could be addressed within the Muslim community using fundamental ideas of the religion in the same way that Muslims have come to deal with banking under Sharia law. The Muslim scholar Sheikh Yusuf Al-Qaradawi (2004) noted how Islamic law deals with bank interest: "The interest on bank accounts is unlawful or haram because such interest is an increase of money made without effort or trade." Allah says, "O you who believe! Fear Allah and give up what remains of your demand for usury if you are indeed believers. If you don't, take notice of war from Allah and His messenger. But if you turn back, you shall have your sums. Deal not unjustly and you shall not be dealt with unjustly" (Qur'an, 2:278).

The underlying rule is that a devout Muslim cannot pay or accept interest. This also means that the typical entrepreneur is barred from seeking or accepting "venture" because the venturer indeed expects a return on his investment, usually a rather generous one. This is clearly a major quandary in the entire question of Nigerian entrepreneurship. What is truly interesting is the ingenuity of the Islamic community in getting around this obstacle. Here is the approach of one UK Bank to the problem of granting mortgages that comply with Sharia law. 
Lloyd's became the third UK bank to offer mortgage services that are compatible with Sharia. The bank purchases the property on behalf of the customers and then leases it back to them in a way which allows them to legally own it at the same time. Therefore, the type of investment is one in which a person deposits money in an account and shares both the risk of making a profit or losing it. The British bank funds up to $90 \%$ of a house's purchase price, and the customer then repays that sum over a fixed period, alongside a rent payment for use of the property. Under the new mortgage, the amount paid over the 25 -year term would be broadly similar to a conventional mortgage.

\section{Economic Impact}

An effort is underway to promote entrepreneurial activity in Nigeria. Rheault and Tortora (2008) argued that there is an abundance of entrepreneurial opportunities for women in Nigeria. The environment for entrepreneurs in Nigeria, while far from hopeless, is nonetheless difficult, especially for women in the northern region. Part of this challenge is reflected by the failure of government efforts to promote entrepreneurial activity. Ojo (2001) contended that efforts by the government and concerned authorities mostly fail to yield the expected result. Unemployment (which along with underemployment is vastly underestimated by government sources) and inflation continue to increase.

As already noted, Nigeria is a nation abounding with economic anomalies. According to reports in the Nigerian Daily Independent (2010), the country anticipates an increase of the gross domestic product for 2010 at $7 \%$ or more.

The current president, Goodluck Jonathon, announced in December 2010 that he is inaugurating a 50 billion naira investment in the nation's infrastructure. None of this is of particular interest to the $70 \%$ of Nigerians who live near, at, or below the poverty level. Nigeria has a number of very wealthy people, but it does yet not have a local consumer class.

If there is to be real, ground-breaking entrepreneurship in Nigeria, it will come from people who realize how to take advantage of a population of 150 million people, determine their real needs, and meet those needs at affordable prices.

Nigeria does not compare well to other emerging nations. It ranks close to the bottom both in terms of the number of start-ups and the number of young, functional businesses. Based on statistics from the CIA Fact book, the GDP per capita in Nigeria is USD $\$ 2,300$, while in Uganda, it is $\$ 1,200$. Still, while $70 \%$ of the Nigerian population lives below the poverty line, only $35 \%$ of Ugandans are in that position. This reflects a truly astounding disparity in income distribution in Nigeria, which is more telling considering that many Nigerian women have no source of income.

The inequity of income distribution is particularly pertinent to women. As Suswam (2010) said,

We assert without any fear of contradiction that women who constitute over $50 \%$ of the Nigerian population produce over $60 \%$ of the total output of national wealth (mostly food and other agricultural products).

Despite their contribution to national wealth production, they receive only $10 \%$ of national incomes and earnings. The gender dimension of poverty and inequality in Nigeria therefore shows that women have less opportunity for earning adequate incomes, access to education, health care, access to positions of power and decision making, less control of the formal economic and other structures of the society in which they live and work.

In northern Nigeria, the bleak situation for entrepreneurial women is further clouded by specific religious factors that have actually become law in that part of the country.

Literature shows that before the 20th century, many women were engaged in entrepreneurial activities such as production of food items from their homes or small-scale agricultural enterprises, activities that are commonly referred to as the informal sector. Women who engage in these small scale enterprises have not legally registered their businesses with the local corporate affairs commission or obtained a tax file number with the federal revenue collection agency, along with any other required government regulations. There are few to no government records that recognize or protect women operating in this unregulated business context (Adeoye, 2010).

In northern Nigeria, Hausa refers as much to ethnicity as to language, and Hausa women are influenced by religious traditions created by male leaders. Midamba and Ekechi (1995) contended that "the intensive, comparative study of Hausa women will show that because of relatively uniform regional historical trends, political and economic factors, and cultural tendencies, the hidden trade indeed prevalent outside Hausa land" (p. 60).

According to Pittin (2002), "marriage, children and productive life in one's husband's home is the goal, the dream and the reality for many Hausa women" (p. 1). This suggests that many Hausa women cannot think of life beyond their traditional roles of taking care of the home and the children. The concept prevailing was that the males will work hard and provide the financial and material sustenance to the family. It is the duty of the 
women to prepare food, to look after the children, and to ensure that everyone in the household is happy and content.

This situation makes it very difficult for such women to even think of starting their own businesses. Further research that speaks directly to Hausa women will formalize the validity of these conclusions with academically acceptable data.

It is true that Hausa women do not generally find much support or approval from men within their community in gaining any financial independence or mobility. Joseph and Najmabadi (2005) pointed out that "there have been occasional notorious acts of violence against women in northern Nigeria that have come before the courts and received widespread publicity" (p. 223). This clearly indicates that society does not give enough consideration to women and that the Islamic community is not ready to accept business ownership by women or to motivate them to engage in any entrepreneurial activities.

From this analysis of the literature related to the position of women in northern Nigeria, it is clear that it is quite difficult for women to develop entrepreneurial skills. Leadership is one of the chief qualities a successful entrepreneur must have. In this male dominated society, the female entrepreneur struggles.

Some of this reflects false understanding and implementation of Sharia. The general belief is that Islam does not give women any freedom. This is a mistaken perception as it indeed provides some freedom to women, including the right to accumulate wealth. Islam does not prevent women from doing business.

The Sokoto Caliphate is a good example of a historic community that supported Islamic teachings and practices that became a powerful empire prior to European colonization, in which women were actively involved in commercial activities. The Sokoto Caliphate reigned at the height of the slave trade in the 17th and 18th centuries and supported a considerable degree of legitimate business transactions that gained access to international markets for small-scale producers, of whom many were women and slaves (Falola \& Heaton, 2008). Clearly, Islam is giving due consideration to women. Conversely, as one can witness more recently, local religious leaders of Islam along with fundamentalist communities may create "false" rules to prevent Muslim women from starting new ventures or working in organizations that challenge the traditional role of women.

Jeppie, Moosa, and Roberts (2010, p. 252) observed that, "women occupied a more prominent role in the Islamic culture of the Sokoto Caliphate than is the case in our classical image of the Middle East." However, Islam insists that a woman must follow some principles aimed at their own benefit.

But the majority of the men from this Hausa land will not accept this, and they may say that women cannot do business because it seems hostile to Islam.

\section{Conclusion}

The current literature provides a solid basis for future comparative analysis. It also offers a number of clues as to what could be culturally acceptable models for addressing the challenges to women entrepreneurs in northern Nigeria. The lack of information specifically about women entrepreneurs in northern Nigeria indicates that socio-cultural factors need to be identified by primary research. Then, guidelines can be created that would provide a framework for successful entrepreneurship by women in accordance with the existing and changing economic conditions in the nation and in the region.

To live in Nigeria is to witness poverty. Although independent since 1960, the current democratic government is only 11 years old. The military regimes that controlled Nigeria for most of the last 50 years perpetuated a system of corruption that curtailed real economic growth, reduced the real tax base, and sent much Nigeria's wealth overseas.

While some women have been part of recent changes, a large segment of the female population has not; the women of Nigeria have been identified by national leaders as one of the great hopes of Nigeria. Further research into this specific geographical area may provide the necessary information for the women of northern Nigeria to be part of that great hope. http://publiceyesite.org/pipermail/jambo_publiceyesite.org/attachments/20100407/766bff31/attachment-0001.pd

[2]. Adeoye, A. (2010). Nigeria’s $65 \mathrm{~m}$ informal workers deserve a union, Nairobi, Kenya: African Economic Research Consortium International House. Retrieved from http://thenationonlineng.net/web3/business/3111.html

[3]. Aigbokhan, B. E. (2000). Poverty, growth and inequality in Nigeria: A case study. Washington, DC: Solidarity Center. Retrieved from http://unpan1.un.org/intradoc/groups/public/documents/idep/unpan003895.pdf

[4]. Ali, A. Y. (2006). The meaning of Holy Qur'an, Beltsville, MD: Amana Publications.

[5]. Ali, M., \& Ali, A. (n.d.). Women's liberation through Islam, Retrieved from http://islamicweb.com/beliefs/women/Liberation.htm

[6]. Alkali, J. (2005, July). Planning sustainable urban growth in Nigeria: Challenges and strategies. Paper presented at Conference on Planning Sustainable Urban Growth and Sustainable Architecture United Nations Headquarters, New York, NY.

[7]. Al-Qaradawi, Y. (2004). Bank interest in the eyes of the Shari'ah. Retrieved from http://www.islamonline.net/servlet/Satellite?pagename=IslamOnline-EnglishAsk_Scholar/FatwaE/FatwaE\&cid=1119503543118\#ixzz0yGdowUOX 
[8]. Atiku on rampage. (14 December 2010). Nigeria Daily Independent. Retrieved from http://digitalizednigeria.com/2010/12/14/atikuon-rampage-nigeria-daily-independent/

[9]. Briggs, I. N. (2007). Nigeria: Mainstreaming trade policy into national development strategies (African Trade Policy Centre Work in Progress No. 52). Addis Abba, Ethiopia: Economic Commission for Africa.

[10]. Central Intelligence Agency. (2011). The World Factbook. Retrieved from https://www.cia.gov/library/publications/the-worldfactbook/geos/ni.html

[11]. Central Intelligence Agency. (2009). The World Factbook. Retrieved from http://www.google.com.ng/search?q=cia+world+factbook\&ie=utf-8\&oe=utf-8\&aq=t\&rls=org.mozilla:enUS:official\&client=firefox-a

[12]. Falola, T., \& Heaton, M. H. (2008). A history of Nigeria, Cambridge, NY: Cambridge Press.

[13]. Federal Secretariat. (2004). Nigeria: National economic empowerment and development strategy. Abuja, Nigeria: National Planning Commission. Retrieved from http://planipolis.iiep.unesco.org/upload/Nigeria/PRSP/Nigeria\%20PRSP.pdf

[14]. Gender Audit (December 2003) in A. Akiyode-Afolabi \& L. Arogundade (Eds.),Election and issues in women's political participation in Nigeria. Abuja, Nigeria: Women Advocates Research and Documentation Centre

[15]. Isiramen, C. (2002). Humanism and women's rights in Nigeria. Retrieved from http://www.iheu.org/node/1134

[16]. Jeppie, S., Moosa, E., \& Roberts, R. (2010). Muslim family law in sub-Saharan Africa: Colonial legacies and post-colonial challenges, Amsterdam: Amsterdam University Press.

[17]. Joseph, S., \& Najmabadi, A. (2005). Encyclopedia of women \& Islamic cultures: Family, jaw, and politics, Brill.

[18]. Kitching, B., \& Woldie, A. (2004), Female Entrepreneurs in Transitional Economies: A Comparative Study of Business women in Nigeria and China." In Proceedings of Hawaii International Conference on Business. Honolulu, HI, Queensland University of Technology, Brisbane, Australia.

[19]. Lawanson, T. (2003). Gender differentials in Nigeria: Implications for sustainable urban development. Akoka, Nigeria: University of Lagos.

[20]. Marković, M. R. (2007). The perspective of women's entrepreneurship in the age of globalization. Charlotte, NC: IAP.

[21]. Meijerink, G., \& Roza, P. (2007). The role of agriculture in economic development, Retrieved from http://www.boci.wur.nl/NR/rdonlyres/98CCE2E3-0FA2-4274-BCA0-20713CA1E125/62608/Fullreport4_Meijerink_Roza.pdf

[22]. Midamba, \& Ekechi. (1995). African market women and economic power: The role of women in African economic development. $\mathrm{F}$. Ekechi, Ed. CT, USA: Greenwood Publishing Group.

[23]. News. (2005). British bank launches Islamic mortgage. IslamOnline. Retrieved from http://www.islamonline.net/English/News/2005-03/22/article03.shtml Nigeria economy. (n.d.), Economy Watch. Retrieved from http://www.economywatch.com/world_economy/nigeria/

[24]. Nigeria human rights report discrimination based on race, sex, religion, disability, language, or social status. (n.d.). Retrieved from ttp://www.ncbuy.com/reference/country/humanrights.html?code=ni\&sec $=5$

[25]. Nwaka, G. (2005, May). The urban informal sector in Nigeria, towards economic development, environmental health and social harmony. Global Urban Development Magazine, $\quad 1(1) . \quad$ Retrieved from http://www.globalurban.org/Issue1PIMag05/NWAKA\%20article.htm

[26]. Ogbu, O. M., Banji, O., \& Mlawa, H. (1995). Chapter 22. Technology and women's ventures in Nigeria's urban informal sector. In O. Ogbu, B. Oyeyinka, \& B. Mlawa (Eds.), Technology Policy and Practice in Africa (p. 380). Retrieved from http://www.gdrc.org/informal/nigeria-UIS.pdf

[27]. Ojo, B. A. (2001). Problems and prospects of sustaining democracy in Nigeria, New York: Nova Publishers.

[28]. Pierce, S. (2003). Farmers and "prostitutes": Twentieth-century problems of female inheritance in Kano Emirate, Nigeria. Journal of African History, 44, 463-86.

[29]. Pittin, R. I. 2002. Women and work in Northern Nigeria: Transcending boundaries. Basingstoke, UK: Palgrave Macmillam. Retrieved from http://www.capri.cgiar.org/pdf/capriwp58.pdf

[30]. Priess, K., \& McCrohan, D. (2006). Global entrepreneurship monitor report: United Arab Emirates. Abu Dhabi, United Arab Emirates: GEM Global Reports, U.S.A.

[31]. Rheault, M., \& Tortora, B. (2008). Nigeria: Drivers and challenges of entrepreneurship. Gallup. Retrieved from http://www.gallup.com/poll/106345/nigeria-drivers-challenges-entrepreneurship.aspx

[32]. Role of Muslim women in the business world. (2009). Retrieved from http://earabgirls.com/role-of-muslim-women-in-the-businessworld/

[33]. Sheikh Al-Qaradawi, Y. (2004). The status of women in Islam. Islamic Emirate. Retrieved from http://www.islamicemirate.com/discover/family-a-gender-roles/298-the-status-of-women-in-islam-by-sh-yusuf-al-qaradawi.pdf

[34]. Surah, (2010). Hadith. Riyad, KSA: Dar-us-Salam Publication.

[35]. Suswan. G. (2010). Education-Nigeria: Suswam decries gender inequality in education. Afrique en ligne. Retrieved from http://www.afriquejet.com/news/africa-news/education-nigeria:-suswam-decries-gender-inequality-in-education2010120262765.html

[36]. Taplin-Dhinoy, S. (2006). Muslim women entrepreneurs. Islamonline. Retrieved from http://www.islamonline.net/servlet/Satellite?c=Article_C\&cid=1156077737744\&pagename=Zone-EnglishMuslim_Affairs\%2FMAELayout

[37]. Soetan, F. (1995).Women's ventures in Nigeria's urban informal sector. Technology policy and practice in Africa. Ottawa, Canada: International Development Research Center. Retrieved from http://www.gdrc.org/informal/nigeria-UIS.pdf

[38]. Thomas, W., Rosa, P., Barabas, S., Balunywa, W., Serwanga, A., Namatovu, R., \& Kyejjusa, S. (2004). Uganda 2004 GEM report. Global Entrepreneurship Monitor. Kampala, Uganda: Global Entrepreneurship Monitor. Retrieved from http://www.gemconsortium.org/files.aspx?Ca_ID=168

[39]. World Bank. (2009, 2011). Nigeria—Kano and Sokoto agricultural development projects. Washington, DC: Author. Retrieved from http://www.worldbank.org/

[40]. Zakaria, Y. (2001). Entrepreneurs at home: Secluded Muslim women and hidden economic activities in northern Nigeria. Nordic Journal of African Studies, 10(1), 107-123. 